\title{
Detection of Rabbit and Bovine Antibodies to the Outer Membrane of Ruminal Bacteroides ruminicola subspecies ruminicola by Enzyme-Linked Immunosorbent Assay (ELISA)
}

\author{
Shigeru Sato, Keiji Ogimoto and Yutaka NaKaI* \\ Department of Animal Microbiology, Tohoku University, \\ Aoba-ku, Sendai-shi 981 \\ * Department of Animal Science, Ibaraki University, \\ Ami-machi Ibaraki-ken $300-03$
}

(Received November 25, 1989)

\begin{abstract}
The enzyme-linked immunosorbent assay (ELISA) was used to detect specific antibodies in rabbit and bovine sera directed to the outer membrane antigen of a ruminal bacteria, Bacteroides ruminicola subsp. ruminicola. Optimal conditions of ELISA were $10 \mu \mathrm{g}$ of the outer membrane antigen per well and 1:500 dilution of antiserum from rabbit immunized with organisms of $B$. ruminicola subsp. ruminicola. The ELISA recognized antibody against $B$. ruminicola subsp. ruminicola subspecies-specifically. Sera from colostrum-deprived calves contained none of specific antibodies, while sera from colostrum-fed calves contained high level of antibodies. The mean titer of sera from 10 day-old calves was significantly $(p<0.01)$ higher than that of 40 day-old calves, but was significantly $(p<0.01)$ lower than that of adult cattle. The mean titer of sera from dairy cows which fed high-roughage diet was significantly $(p<0.01)$ higher than that of feedlot cattle which fed high-concentrate diet. The results suggest that the antibodies against the outer membrane antigen of $B$. ruminicola subsp. ruminicola transfer to calves via the colostrum, and that the antibody levels of cows are affected by the way of feed management.
\end{abstract}

Jpn. J. Zootech. Sci., 61 (8): 719-724, 1990

Key words: Bacteroides ruminicola, bovine antibody, ELISA, outer membrane, rumen bacteria

Most of natural antibodies are considered to be produced in responses to continuous low levels of antigenic stimulation of indigenous microflora ${ }^{1,2)}$. The rumen provides particularly favourable conditions to rumen bacteria as stimulaters for natural antibodies production $^{18)}$. Serological techniques have been used to identify individual strains of rumen bacteria, e.g. Butyrivibrio ${ }^{3,8)}$, Selenomonas ${ }^{4)}$ and Bacteroides ${ }^{11,17}$, however, have not been applied to investigate the host immune respon- ses to rumen bacteria. On the other hand, using the outer membrane or its components such as polysaccharide and lipopolysaccharide (LPS), enzyme-linked immunosorbent assay (ELISA) was performed for detecting antibodies against anaerobic infections in human ${ }^{7,12,20)}$. Previously $\mathrm{we}^{13)}$ reported that the antibodies against the outer membrane antigen of ruminal Bacteroides succinogenes transferred to calves via the colostrum, and that the titers of cows were affected by the way of feed management. 
In the present study, we firstly determined the optimal conditions of ELISA with the outer membrane antigen of Bacteroides ruminicola subsp. ruminicola and investigated specificity of the methods using immunized rabbit serum, and applied the ELISA to detect specific antibodies in sera from calves and cattle.

\section{Materials and Methods}

Bacterial strains: Standard strains of $B$. ruminicola subsp. ruminicola, $B$. ruminicola subsp. brevis, B. succinogenes and Selenomonas ruminantium were used. Media and growth conditions of the bacterial strains were described previously ${ }^{15}$.

Rabbit immunization: Rabbit antisera to intact bacterial organisms were prepared as described previously ${ }^{13}$. Briefly, the animals were inoculated intravenously 6 times in the first 2 weeks. A booster injection was performed at the fourth week, and the animals were phlebotomized at the fifth week. Each inoculum dose was $5 \times 10^{9}$ live organisms in $0.15 \mathrm{M} \mathrm{NaCl}$.

Preparation of the outer membrane: The outer membrane of $B$. ruminicola subsp. ruminicola was prepared by the methods of heat, EDTA treatment, shearing, and differential centrifugation as described previously ${ }^{15}$.

ELISA : ELISA was performed as described previously ${ }^{13}$. Briefly, wells of microtiter plate were coated with the outer membrane antigen of $B$. ruminicola subsp. ruminicola. After the wells were washed, rabbit antiserum or bovine serum was added. Then, after wash, horseradish peroxidase conjugated anti-rabbit immunoglobulin ( $\mathrm{Ig}) \mathrm{G}(\mathrm{H}+\mathrm{L})$ goat serum or antibovine $\operatorname{IgG}(\mathrm{H}+\mathrm{L})$ rabbit serum was added as secondary antibody. Substrate was o-phenylendiamine suspended in $0.1 \mathrm{M}$ citrate buffer (pH 4.0) containing $0.3 \% \mathrm{H}_{2} \mathrm{O}_{2}$. Optical density (OD) at $492 \mathrm{~nm}$ was read in Immuno Reader ( $\mathrm{NJ}-2000$, Nippon Inter Med.). Optimal conditions of ELISA were determined by using various quantities of the antigen $(0.25 \mu \mathrm{g}$ to $25 \mu \mathrm{g}$ per well), various dilutions of the rabbit antiserum $(1: 50,000$ to $1: 100)$, a constant dilution of enzyme-conjugated antibody $(1: 2,000)$, and a constant reaction time $(30$ $\min$ ).

Bovine sera: Serum samples were obtained from 24 calves of Japanese Black breed at colostrum-deprived 0 day, and colostrum-fed 10 days and 40 days after birth. Serum samples were also obtained from 50 adult cattle of Holstein-Friesian breed, including 25 dairy cows which fed high-roughage diet and 25 feedlot cattle which fed high-concentrate diet.

Measurement of serum IgG : Concentrations of IgG in sera from calves were measured by single radial immunodiffusion (SRID) kit (ICN ImmunoBiologicals, Israel).

\section{Results}

Standardization of ELISA: When antigens ranging from $0.25 \mu \mathrm{g}$ to $25 \mu \mathrm{g}$ per well were tested (Fig. 1), the curves for two serum dilutions $(1: 500$ and $1: 1,000)$ were similar. The ELISA values increased under concentrations between $0.25 \mu \mathrm{g}$ and $10 \mu \mathrm{g}$ of the antigen. At concentrations between $10 \mu \mathrm{g}$ and $25 \mu \mathrm{g}$ of the antigen, the curve leveled off. When antiserum dilutions between $1: 50,000$ and $1: 100$ were tested at $10 \mu \mathrm{g}$ antigen per well

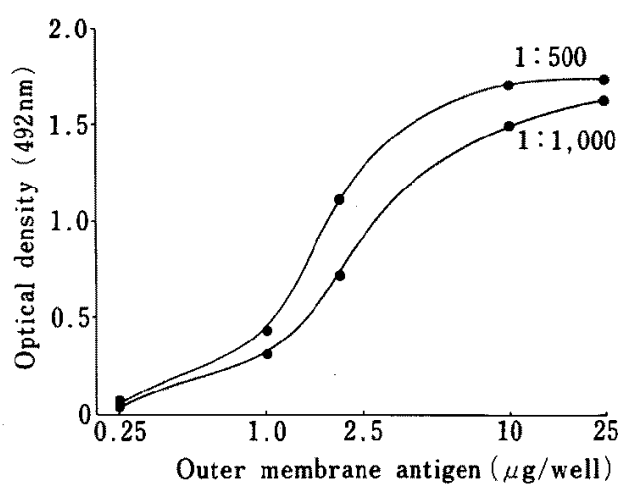

Fig. 1. ELISA values of rabbit antiserum against $B$. ruminicola subsp. ruminicola $(1: 500$ and $1: 1,000)$ in various quantities of the antigen. 
(Fig. 2), the ELISA values increased at serum dilutions between $1: 5,000$ and $1: 500$. Therefore, $10 \mu \mathrm{g} /$ well of the outer membrane antigen and rabbit antiserum diluted 1:500 were chosen for subsequent tests.

Specificity of ELISA to B. ruminicola subsp. ruminicola: Specificity of ELISA was determined by using $10 \mu \mathrm{g}$ per well of the outer membrane antigen of $B$. ruminicola subsp. ruminicola and $1: 500$ diluted rabbit antisera raised against some rumen bacterial species (Table 1). The ELISA value of the homologous antiserum was high (1.62), while the ELISA values were negligible level in the heterologous antisera to the other bacterial species such as $B$. ruminicola subsp. brevis, $B$. succinogenes and $S$. ruminantium. The value was also negligible in the homologous antiserum absorbed with $B$. ruminicola subsp. ruminicola.

Detection of bovine antibodies against the outer membrane of $B$. ruminicola subsp. rumi-

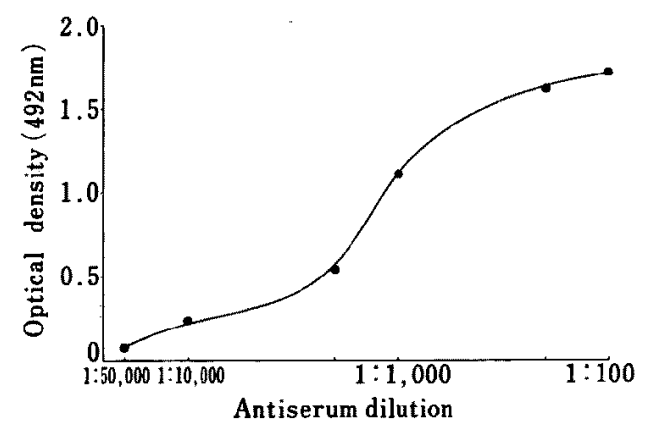

Fig. 2. ELISA values of various dilutions of rabbit antiserum in a constant outer membrane antigen of $B$. ruminicola subsp. ruminicola $(10 \mu \mathrm{g} /$ well $)$. nicola by ELISA : Bovine antibodies specific to $B$. ruminicola subsp. ruminicola were investigated by the ELISA. At bovine serum dilutions between $1: 5,000$ and $1: 10$, ELISA values showed sigmoid curve at $10 \mu \mathrm{g}$ antigen per well.

The ELISA values of sera from calves and adult cattle were estimated under conditions of $10 \mu \mathrm{g}$ antigen per well, $1: 1,000$ to $1: 10$ serum dilution, $1: 1,500$ enzyme-conjugated dilution and $30 \mathrm{~min}$ reaction (Table 2 ). The titers of sera from colostrum-deprived calves were not detectable level, while those of sera from colostrum-fed calves were high. Adult cattle showed higher titer than calves. The values of individual animal at $1: 100$ serum dilution were plotted in Fig. 3. The titers of sera from colostrum-fed calves varied from calf to calf, i.e. those from 4 calves of 10 day-old and 19 calves of 40 day-old were not detectable level. The mean titer of sera from 10 day-old calves was significantly $(p<0.01)$ higher than that of 40 day-old calves, but was significantly ( $p<$

Table 1. ELISA values of the outer membrane antigen of $B$. ruminicola subsp. ruminicola ( $10 \mu \mathrm{g} /$ well) against the homologous and heterologous rabbit antisera $(1: 500)$

\begin{tabular}{lc}
\hline \hline Rabbit antisera & ELISA value \\
\hline anti-B. ruminicola subsp. ruminicola & 1.62 \\
anti-B. ruminicola subsp. ruminicola & 0.03 \\
absorbed by the organisms & 0.04 \\
anti-B. ruminicola subsp. brevis & 0.16 \\
anti-B. succinogenes & 0.01 \\
anti-S. ruminantium & \\
\hline
\end{tabular}

Table 2. ELISA values of calves and cattle, with use of a constant outer membrane antigen of B. ruminicola subsp. ruminicola $(10 \mu \mathrm{g} /$ well $)$ and various dilutions of sera

\begin{tabular}{|c|c|c|c|c|c|}
\hline \multirow{2}{*}{$\begin{array}{l}\text { Serum } \\
\text { dilution }\end{array}$} & \multicolumn{3}{|c|}{ Calves } & \multicolumn{2}{|c|}{ Adult cattle } \\
\hline & $\begin{array}{l}0 \text { day-old } \\
(\mathbf{n}=24)\end{array}$ & $10 \underset{(n=24)}{\text { day }- \text { old }}$ & $\begin{array}{l}40 \text { day-old } \\
(\mathrm{n}=24)\end{array}$ & $\begin{array}{c}\text { Dairy cow } \\
(n=25)\end{array}$ & $\begin{array}{l}\text { Feedlot cattle } \\
(\mathrm{n}=25)\end{array}$ \\
\hline 1: & 0 & $0.69 \pm 0.28$ & $0.32 \pm 0.30$ & $1.20 \pm 0.33$ & $0.85 \pm 0.32$ \\
\hline $1: 100$ & 0 & $0.21 \pm 0.24$ & $0.10 \pm 0.23$ & $0.77 \pm 0.23$ & $0.52 \pm 0.23$ \\
\hline 1: 500 & 0 & $0.01 \pm 0.15$ & $0.01 \pm 0.14$ & $0.38 \pm 0.15$ & $0.29 \pm 0.15$ \\
\hline $1: 1,000$ & 0 & $0.01 \pm 0.11$ & $0.01 \pm 0.10$ & $0.21 \pm 0.11$ & $0.16 \pm 0.15$ \\
\hline
\end{tabular}

ELISA values are expressed as Mean $\pm \mathrm{SD}$. 


\section{Sato, Ogimoto and NaKaI}

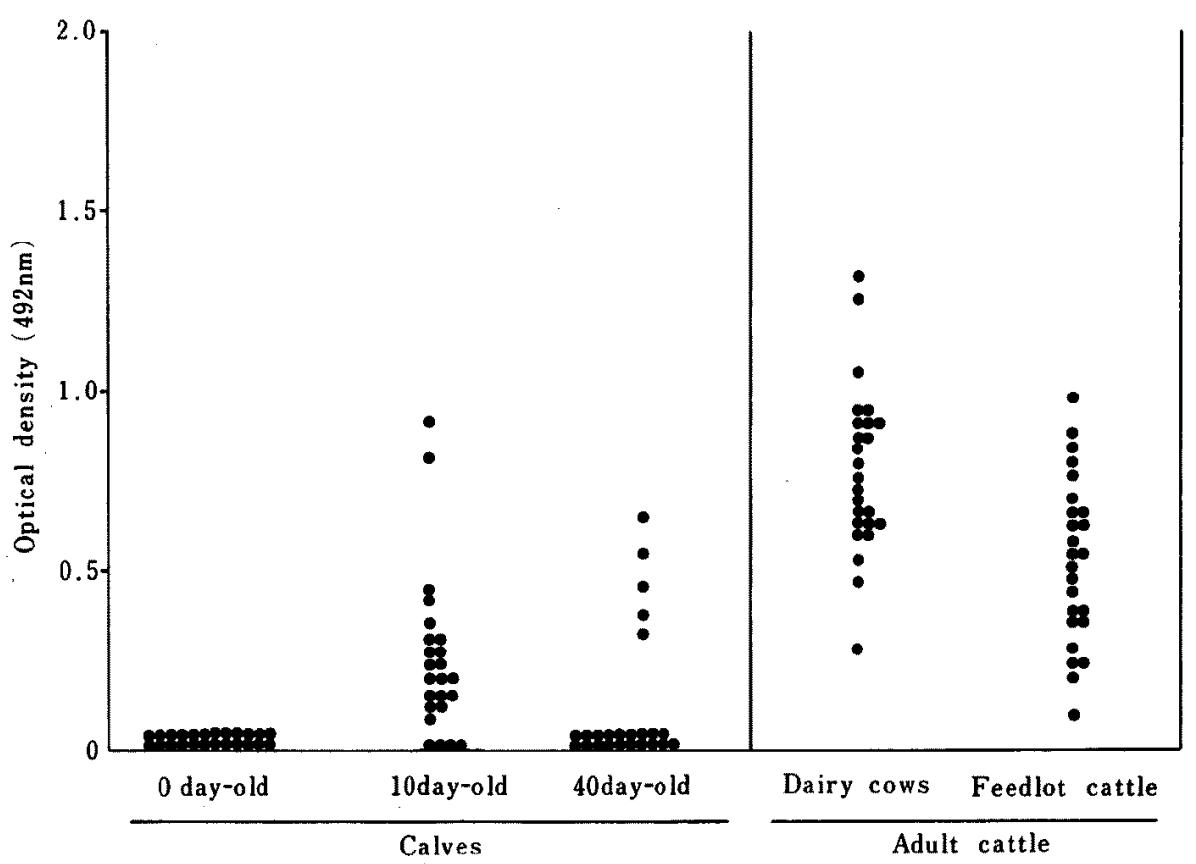

Fig. 3. ELISA values of calves and adult cattle, with use of the outer membrane antigen of $B$. ruminicola subsp. ruminicola $(10 \mu \mathrm{g} /$ well) and bovine sera $(1: 100)$.

0.01) lower than that of adult cattle. The mean titer of sera from dairy cows was significantly $(p<0.01)$ higher than that of feedlot cattle and the highest in the experiment.

Total IgG level of calf sera : Concentrtions of $\mathrm{IgG}$ in sera from colostrum-deprived calves were not detectable level, and those of 10 day-old calves $(19.5 \pm 4.5 \mathrm{mg} / \mathrm{ml}$, Mean $\pm \mathrm{SD}$ ) were significantly $(\mathrm{p}<0.05)$ higher than those of 40 day-old calves $(15.7 \pm 5.3 \mathrm{mg} / \mathrm{ml})$. There were positive correlation between the ELISA values (1:100 serum dilution) and total IgG level with relatively low coefficient of correlation $(0.423)$.

\section{Discussion}

It was demonstrated that the outer membrane of $B$. ruminicola subsp. ruminicola possessed subspecies-specific antigen by immunodiffusion, indirect immunofluorescent test and immunoelectron microscopy ${ }^{16}$. The present ELISA study also showed no crossreactivity of the outer membrane of $B$. ruminicola subsp. ruminicola to $B$. ruminicola subsp. brevis, $B$. succinogenes and $S$. ruminantium. Thus the outer membrane antigen of $B$. ruminicola subsp. ruminicola is considered to be subspecies-specific.

Generally newborn calves acquire passive immunity soon after birth by the intestinal absorption of antibodies present in the dam's colostrum $^{6,19)}$, and the initial increase in concentration of Igs in serum of the calves decreases during the subsequent 8-16 days by biological degradation ${ }^{5)}$. The present observation of increase and subsequent decrease in total IgG concentration in sera from colostrum-fed calves was correspondent to this general agreement. In the present study, specific antibodies against the outer membrane antigen were not detected from colostrumdeprived calves but from colostrum-fed calves. Similar results were obtained in antibodies against the outer membrane antigen of $B$. succinogenes ${ }^{13)}$. These results suggest that the antibodies to the outer membrane antigen of 
rumen bacteria such as $B$. ruminicola subsp. ruminicola and $B$. succinogenes transfer to calves via the colostrum, as was suggested by SHARPE et al. ${ }^{18)}$. The antibodies transferred to calves may influence the settlement of microbial flora in the rumen of newborn calves.

The mean titer of sera from dairy cows was higher than that of feedlot cattle. The relationship between microflora in the rumen and various kinds of feed rations has been published. $B$. ruminicola is the most predominant ammonia-producing bacteria in the rumen of mature cattle ${ }^{21}$, and is the most numerous bacteria in heifers fed a high proportion of hay ${ }^{10)}$. OGImoto et al. ${ }^{9)}$ demonstrated that the agglutinating titers of antibodies against $B$. ruminicola were higher in grazing cattle than in feedlot cattle. Therefore, the difference of antibody titers between dairy cows and feedlot cattle may reflect the different rumen bacterial populations. The results suggest that the antibody levels against the outer membrane of B. ruminicola subsp. ruminicola are affected by the way of feed management.

Although the antibodies against rumen bacteria are considered to be natural antibodies $^{2,18)}$, the mechanism of antibody production and immunological roles in host protection have not been revealed. The ELISA is useful technique to investigate bovine immune responses to rumen bacteria, and it can be applied to detect secretory antibodies as well as serum antibodies of specific Ig classes. It is suggested that the rumen microbial flora may stimulate antigenically host immune system, and play an important role in the development of immune system in calves ${ }^{14)}$. Further investigations are needed to reveal the relationships between development of immune system and settlement of rumen microbial flora in calves.

\section{References}

1) BERG, R.D, and D.C. SAVAGE, Immunological response and microorganisms indigenous to the gastrointestinal tract. Am. J. Clin. Nutr., 25 : 1364-
1371. 1972

2) Boyden, S.V., Natural antibodies and the immune response. Adv. Immunol., $6: 1-28.1966$.

3) Hazlewood, G.P., M.K. Theodorou, A. Hutchings, D.J. JoRdan and G. Galfre, Preparation and characterization of monoclonal antibodies to a Butyrivibrio sp. and their potential use in the identification of rumen Butyrivibrios, using an enzyme-linked immunosorbent assay. J. Gen. Microbiol., 132 ; 43-52. 1986.

4) Hobson, P.N., S.O. MANN and W. SMith, Serological tests of a relationship between rumen selenomonads in vitro and in vivo. J. Gen. Microbiol., 29 : 265-270. 1962.

5) Husband, A.J., M.R. Brandon and A.K. Lascelles. Absorption and endogenous production of immuno-. globulins in calves. Aust. J. Exp. Biol. Med. Sci., 50 : 491-498. 1972.

6) IstikAwA, H. and T. Konishi, Changes in serum immunoglobulin concentrations of young calves. Jpn. J. Vet. Sci., $44: 555-563.1982$.

7) MANShEIM, B.J, and D.L. KASPER, Detection of anti-capsular antibodies to Bacteroides asaccharolyticus in serum from rabbits and humans by use of an enzyme linked immunosorbent assay. J. Infect. Dis., 140 : 945-951. 1979.

8) Margherita, S.S., R.E. Hungate and H. Storz, Variation in rumen Butyrivibrio strains. J. Bacteriol., 87: 1304-1308. 1964.

9) Ояммото, K., M. Fukumoto and T. Inamoto, Immune response of the domestic ruminant to the rumen bacterial species: Agglutination titers of sera from grazing cattle, feedlot cattle and sheep. Jpn. J. Zootech. Sci., 54 : 33-38. 1983.

10) Oshio, S., I. Tahata and H. Minato, Effect of diets differing in ratios of roughage to concentrate on microflora in the rumen of heifers. J. Gen. Appl. Microbiol., 33 : 99-111. 1987.

11) Poxton, I.R., R. Brown and J.G. Colles, Detection of species-specific and cross-reactive cell surface antigens of Bacteroides species by an indirect enzymelinked immunosorbent assay. J. Med. Microbiol., 15 : 223-231. 1982.

12) Rissing, J.P., T.B. Buxton, R. Harfis and W. MOORE, Assessment of lipopolysaccharide and outer membrane of Bacteroides fragilis by an antibodyinhibition enzyme-linked immunosorbent assay in physiologic fluids and infected animals. J. Lab. Clin. Med., 98 : 784-794. 1981.

13) SAto, S., K. OGImoto and Y. NAKAl, Detection of bovine antibodies to the outer membrane of ruminal Bacteroides succinogenes by enzyme-linked immunosorbent assay (ELISA). Jpn. J. Vet. Sci., 52 : 29-34. 1990.

14) Sato, S., K. OGimoto and Y. NaKaI, Comparative distribution of immunoglobulin-containing cells in stomach, intestine and associated lymph nodes of cattle. Jpn. J. Vet. Sci., $52: 63-70.1990$. 


\title{
Sato, Ogimoto and Nakai
}

15) Sato, S., K. Ogimoto and Y. NaKal. Serological and morphological observation on the outer membrane of Bacteroides succinogenes. Jpn. J. Vet. Sci., 52 : 163164. 1990.

16) Sato, S., K. Ogimoto and Y. Nakal, Serological and morphological observation on the outer membrane of ruminal Bacteroides ruminicola subspecies ruminicola. Jpn. J. Zootech. Sci, $61: 714-718$. 1990 .

17) Sharpe, M.E, Serology of rumen Bacteroides. J. Gen. Microbiol., 67 : 273-288. 1971.

18) Sharpe, M.E., M.J. Latham and C. RetTer, The occurrence of natural antibodies to rumen bacteria. J. Gen. Microbiol., 56 : 353-364. 1969.
19) Stott, G.H., D.B. MarX, B.B. Menefee and G.T. Nightengale, Colostral immunoglobulin transfer in calves. II. The rate of absorption. J. Dairy Sci., 62 : 1766-1773. 1979.

20) Tolo, K. and K. Schenck, Activity of serum immunoglobulins $G, A$, and $M$ to six anaerobic, oral bacteria in diagnosis of periodontitis. J. Period. Res., 20 : 113-121. 1985

21) Wallace, R.J. and M. Brammall, The role of different species of bacteria in the hydrolysis of protein in the rumen. J. Gen. Microbiol., 131: 821832. 1985.

\section{酵素免疫測定法（ELISA）によるウサギおよびウシ 血清中の抗 Bacteroides ruminicola subspecies ruminicola 外膜抗体の検出}

\author{
佐藤 繁・扇元敬司・中井 裕 ${ }^{*}$ \\ 東北大学農学部，仙台市青葉区 981 \\ *茨城大学農学部, 茨城県阿見町 300-03
}

酻素免疫測定法（ELISA）によりルーメン由来 Bacteroides ruminicola subsp. ruminicola の 菌体外膜に対するウサギおよびウシ血清中の特異抗体を検索した．ELISAの反応条件は外膜抗原濃度 が $10 \mu \mathrm{g} /$ well，また，抗菌体ウサギ血清の希橎倍率は $1: 500$ とした. B. ruminicola subsp. ruminicola の外膜抗原は同菌種の抗菌体血清之特異的に反応し, B. ruminicola subsp. brevis, B. succinogenes および Selenomonas ruminantium の抗菌体血清との間に交差反応は認められな かった. ELISA によりウシ血清中の特異抗体を検索した結果, 初乳摄取前の子牛では抗体が全く検出 されず，初乳摂取後には摂取前に比べ高值を示した，10日踰時の平均抗体価は，40日榆時に比べ有意 （p<0.01）な高值を示し, また, 成牛に比べ有意 $(p<0.01)$ な低值を示した. 粗飼料を多く給与さ れた乳牛の平均抗体価は，濃厚飼料を多く給与された肥育牛に比べ有意（p<0.01）な高値を示した。 これらの結果加ら，抗 B. ruminicola subsp. ruminicola 外膜抗体は，初乳を介して子牛に移行す ること，また，成牛では飼養管理条件によって抗体価に差異があることが示唆された。

日畜会報，61 $(8): 719-724,1990$ 